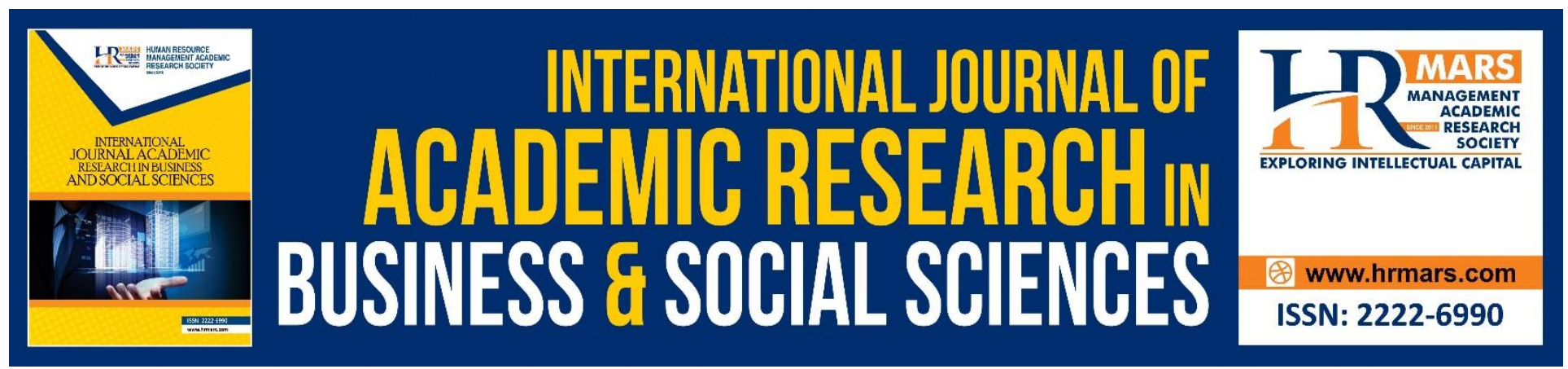

\title{
Ethical Leadership in Educational Administration: A Review
}

\section{Wan Mohd Hafis Pak Wan Chik}

To Link this Article: http://dx.doi.org/10.6007/IJARBSS/v10-i9/8024

DOI:10.6007/IJARBSS/v10-i9/8024

Received: 21 July 2020, Revised: 18 August 2020, Accepted: 01 September 2020

Published Online: 29 September 2020

In-Text Citation: (Chik, 2020)

To Cite this Article: Chik, W. M. H. P. W. (2020). Ethical Leadership in Educational Administration: A Review. International Journal of Academic Research in Business and Social Sciences. 10(9), 1139-1151.

\section{Copyright: (C) 2020 The Author(s)}

Published by Human Resource Management Academic Research Society (www.hrmars.com)

This article is published under the Creative Commons Attribution (CC BY 4.0) license. Anyone may reproduce, distribute, translate and create derivative works of this article (for both commercial and non-commercial purposes), subject to full attribution to the original publication and authors. The full terms of this license may be seen

at: http://creativecommons.org/licences/by/4.0/legalcode

Vol. 10, No. 9, 2020, Pg. 1139 - 1151

Full Terms \& Conditions of access and use can be found at http://hrmars.com/index.php/pages/detail/publication-ethics 


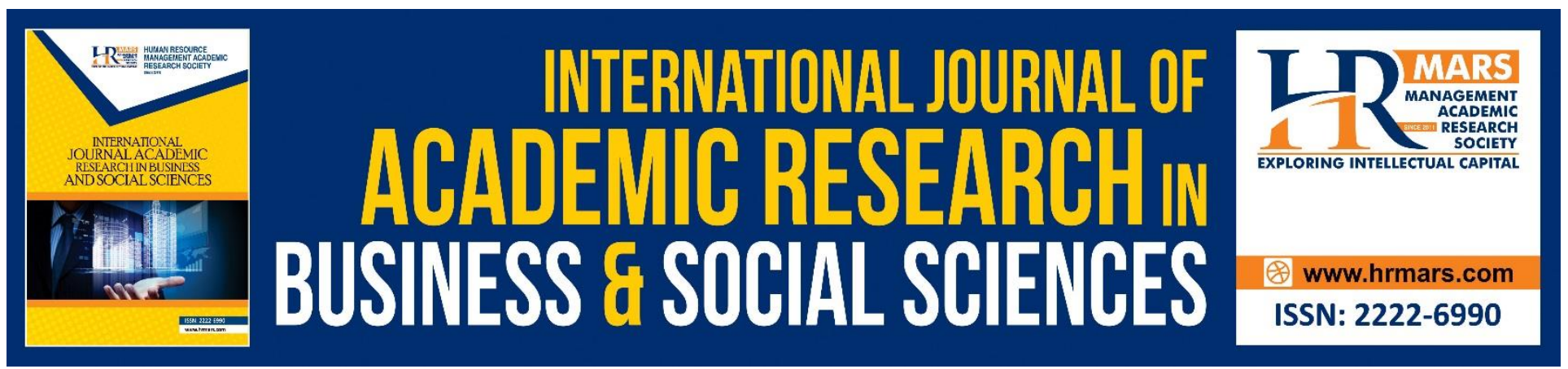

\title{
Ethical Leadership in Educational Administration: A Review
}

\author{
Wan Mohd Hafis Pak Wan Chik \\ Universiti Pendidikan Sultan Idris, Malaysia
}

\section{Abstract}

Purpose - This study is to outline the main findings from an international literature review focused on ethical leadership. This synthesizes all the opportunities and potentials in the education administration in Malaysia to outline patterns in the future of research.

Design/methodology/approach - This review is based on an analysis of empirical articles published in indexed journals between 1991 and 2019.

Findings - This paper uses the basics of contemporary knowledge to explore: the contextual pattern of ethical leadership research so far.

Research limitations/implications - This study is based on studies in different countries, using various conceptual frameworks. The limitation is the scope of the sample. This study also does not include studies conducted in Malaysia.

Practical implications - The results of this study provide information on improving the quality of ethics in educational leadership.

Originality/value - The author recommends widening the scope of the sample examined to further clarify the concept of ethical leadership and its implications to the practice of educational leadership. Keywords: Ethics, Education Management, Ethical Leadership, Decision Making, Educational Administration

\section{Introduction}

Ethical leadership is critical to a leader's credibility and his or her potential to influence (Den Hartog and Belschak, 2012). The credibility of ethical leaders may have an important effect on the trust between leaders and followers (Eisenbeiss and Giessber, 2012).

Looking at ethics through different paradigms is a phenomenon that has been overlooked lately. Therefore, several studies have been developed that address ethical dilemmas from various perspectives. When we look at existing studies, it appears that scientists and industry practitioners are involved in professional ethical issues, but none have adopted the concept of professional ethics as a separate paradigm. 
In recent years, many researchers across the United States and other countries have begun to incorporate ethical leadership concepts into their dissertations. Ethical leadership is defined in management as appropriate normal behavior through personal actions and interpersonal relationships, encouraging such behavior to followers through bilateral communication, enforcement, and decision making (Brown, Trevino, \& Harrison, 2013). Ethical leaders set a good example of being honest and principled leaders and striving to do the right thing while leading a personal life in an ethical way and tend to make fair and balanced decisions (Bodner, 2013).

Ethical leaders set a standard, communicate, and enforce clear ethical standards among organizational members, and provide support, concern, and trust to subordinates (Brown et al., 2013). Ethical leaders tend to be role models that motivate subordinates to follow their example (Symlie, 2014; Brown \& Trevino, 2006). Empirical studies of ethical leadership have confirmed that there is a direct link between managers' ethical leadership and some ethical and non-ethical behaviors.

Examples that motivate subordinates to follow their example (Symlie, 2014; Brown \& Trevino, 2006). Empirical studies of ethical leadership have confirmed that there is a direct link between managers' ethical leadership and some ethical and non-ethical behaviors.

\section{Ethical Leadership}

Since the last thirty years, there has been an increase in research on ethical leadership in education (Lapointe et al., 2010). In the late 1970s, Hodgkinson (1978) called for the restoration of the basic ethical theory of educational leadership. A few years later, Greenfield (1981) and Foster (1986) emphasized the need for further research into the ethics and ethical aspects of educational leadership.

Starratt (1991) was one of the first to propose a conceptual framework for ethical leadership and to suggest that leadership ethics should no longer be defined as style but as a basis for ethical dimensions and actions. Sergiovanni (1992) pursues this approach in his ethical model by integrating concerns for collective and individual interests and interests.

Productivity and efficiency are often the key actors; however, there is a point of view, claiming that it is the leader's responsibility to maintain ethical standards and ethical conduct. School Ethics Leadership Theory was first reviewed by Sergiovanni (Sergiovanni, 1992), who reviewed the literature on previous research, in his book Ethical Leadership: Finding School Improvement. According to him, leadership is about more than just technique; Ethical leadership, should be at the center of the leadership, can be understood as a school leader applying every possible means, in accordance with ethical authority, to stimulate the potential of the individual, to make his followers, and to form a noble one.

Along the same lines, the study argues that leaders' ethical leadership refers to school staff to pursue an unacceptable ethical appeal, based on its ethical integrity, so that ethics and values are properly affirmed, staff sense of responsibility and responsibility are inspired, and continue to raise 
INTERNATIONAL JOURNAL OF ACADEMIC RESEARCH IN BUSINESS AND SOCIAL SCIENCES Vol. 10, No. 9, 2020, E-ISSN: 2222-6990 @ 2020 HRMARS

their awareness of their work, their dedication to school development, and their collective efforts to achieve the vision of school development.

In Asia, however, ethical leadership research has begun to spread widely since the mid-1990s in Taiwan. Yan Tongwen (Yan, 2002) from the University of Taiwan concludes that ethical leadership encompasses six dimensions: 1) the most specific implementation of ethical leadership from postmodern achievement; 2) the spirit of ethical leadership focuses on the charms of individual leaders; 3) the enforcement of ethical leadership is established on the basis of authority; 4) The purpose of ethical leadership is to nurture its members with values driven by obligations; 5) the role of ethical leadership is proactive but not backward; 6) Ethical leadership's dream of establishing a welfare school for children.

In recent years, a more comprehensive and in-depth study of ethical leadership theory has been carried out. Academics offer differing opinions on the structure of ethical leadership, with representative views as follows. (Resick et al., 2006) defines the main characteristics of an ethical leader based on western literary views on leadership and ethics. With data gathered from Global Leadership and the Effectiveness of Organizational Behaviour and through analysis, they propose dimensions of ethical leadership, namely Integrity, Altruism, Collective Motivation, and Incentives, that play an important role in leadership effectiveness based on cultural background.

Langlois and Lapointe (2007) have identified three themes of principled leadership practiced by principals namely criticism, justice and concern. They find that newly appointed principals are more inclined to the theme of justice leadership. Whereas senior principals and teachers are able to work on the three elements, criticism, justice and concern are best.

Karakose (2007) conducted a quantitative study of teachers 'perceptions of their school leaders' ethical leadership. Karakose uses the Ethical Leadership Scale questionnaire developed by Yilmaz (2006) and contains four dimensions namely ethical communication, ethical climate, ethical decision making and ethical behavior. However, the study assessed demographics only. Therefore, a more in-depth study is needed.

However, (Ladkin, 2008) believes that "ethical leadership" has three main dimensions: selfmastery and environment, coordination, self-image, purpose and consistency in terms of information, and the purpose, of specific goals being achieved. He considers that "ethical leadership" should play a part in the efforts of leaders, and question whether it is guided by "working hard for the best interests of the living".

Meanwhile, a multi-dimensional approach was performed by Kalshoven et al. (2011), where he developed seven multidimensional ethical leadership. All seven dimensions are human-oriented, justice, power-sharing, concern for sustainability, ethical guidance, role clarity and integrity. Patterson et.al, (2013) concludes that management plays an important role in implementing educational reforms, while striving to maintain its own priorities and values. 
Further, many international studies on ethical leadership have raised several questions (Cherkowski et al., 2015; Kristinsson, 2014; Langlois \& Lapointe, 2010, 2014): Does an ethical leader have the same meaning without any historical, religious or religious considerations specific culture? Finding answers to these questions can foster a better understanding of both national habits and universal equations related to ethical leadership, as well as cultural and social features that facilitate or hinder the development of leadership ethics.

This is a bit different when we look at the study (Viet, 2015), which states that organizational ethical leadership is focused on structure and efficiency and comes with decision-making power. It's transactional. Ethical leadership is focused on adherence to the rules of the game through a performance evaluation system and a reward system and requires self-control. Leadership is responsible for the return on investment of shareholders and for compliance with the law (Viet, 2015). Ethical leadership in organizations shows adherence to internal and external regulations through remuneration (Viet, 2015).

A study was conducted to explore school principals' judgment that led to their decision not to meet the national and comprehensive national reform guidelines. This qualitative study was based on interviews with 59 school principals. Generating a theme is an inductive process, based on various perspectives articulated by the principal. And consider the characteristics and circumstances of the school (Schechter \& Shaked, 2017).

Dinc (2018) has examined the direct and indirect effects of the relationship between ethical leadership, types of ethical climate, aspects of job satisfaction, organizational commitment components and organizational citizenship behaviour dimensions of 515 employees working in public and private universities in Bosnia and Herzegovina.

Lowery (2019) conducted a study on principals' perceptions of south-eastern Ohio on decision-making ethics. He found that principals' perceptions varied in their familiarity and comfort with moral literacy. The overarching themes that emerge from this analysis find the connection between ethical dilemmas, becoming leaders of moral knowledge, dimensions of moral leadership, and integration of ethical and ethical values.

In the same year, a study on the ethical behaviour of school leaders in non-Euro-West countries by examining the difficulties faced by Kenyan integrity leaders was conducted. The study highlights the importance of contextual variables in influencing leaders' decisions, reflecting tensions between liberal and communist ethical approaches. Despite similar challenges faced by those working in the euro-western context, Kenyan leaders face additional challenges for working with Ubuntu's cultural values: maintaining an entire community, harmonious work relationships, brotherly loyalty and senior citizenship (Oduol \& Cornforth, 2019). 
INTERNATIONAL JOURNAL OF ACADEMIC RESEARCH IN BUSINESS AND SOCIAL SCIENCES Vol. 10, No. 9, 2020, E-ISSN: 2222-6990 (C) 2020 HRMARS

Table 1. Chronology of the Development of Ethical Leadership Studies (1991-2019)

\begin{tabular}{|c|c|c|}
\hline YEAR & AUTHOR & STUDY \\
\hline 1991 & Starratt & $\begin{array}{l}\text { - the model focuses on the development of ethics in the context of } \\
\text { the school, which consists of three basic themes that school } \\
\text { leaders should consider. } \\
\text { - the three basic themes are criticism, justice and concern }\end{array}$ \\
\hline 1992 & Sergiovanni & $\begin{array}{l}\text { - pursue this approach in their ethical model by integrating } \\
\text { concerns for collective and individual interests and interests. }\end{array}$ \\
\hline 1998 & $\begin{array}{l}\text { Kanungo } \\
\text { and } \\
\text { Mendonca }\end{array}$ & $\begin{array}{l}\text {-develop an ethical leadership model through three dimensions: } \\
\text { leader motives; leadership influence strategies; and the formation } \\
\text { of a leader character. }\end{array}$ \\
\hline 1998 & $\begin{array}{l}\text { Craig and } \\
\text { Gustafson }\end{array}$ & $\begin{array}{l}\text {-developed the Perceived Leadership Integrity Scale (PLIS) } \\
\text { instrument. }\end{array}$ \\
\hline $\begin{array}{l}1998, \\
2000\end{array}$ & $\begin{array}{l}\text { Dempster, } \\
\text { Freakley and } \\
\text { Parry }\end{array}$ & $\begin{array}{l}\text { - conducted a study in Queensland, Australia with the focus of their } \\
\text { study on school principals' perceptions of ethical climate. }\end{array}$ \\
\hline 2002 & Yan & - concludes that ethical leadership encompasses six dimensions \\
\hline 2005 & $\begin{array}{l}\text { Brown, } \\
\text { Treviño and } \\
\text { Harrison }\end{array}$ & $\begin{array}{l}\text { - the development of instruments that measure the more scientific } \\
\text { ethical leadership, the Ethical Leadership Scale (ELS). } \\
\text { - the ELS contains } 10 \text { items and measures ethical leadership in the } \\
\text { form of unidimensional. }\end{array}$ \\
\hline 2006 & $\begin{array}{l}\text { Resick, } \\
\text { Hanges, } \\
\text { Dickson and } \\
\text { Mitchelson }\end{array}$ & $\begin{array}{l}\text { - determine the main characteristics of an ethical leader based on } \\
\text { western literature on leadership and ethics. }\end{array}$ \\
\hline 2006 & Yilmaz & - developed the Ethical Leadership Scale quest \\
\hline 2007 & $\begin{array}{l}\text { Langlois and } \\
\text { Lapointe }\end{array}$ & $\begin{array}{l}\text { - conducted a qualitative study in seven regions of Canada in an } \\
\text { open interview of } 47 \text { principals. } \\
\text { - Identify three themes of principled leadership practiced by } \\
\text { principals: criticism, justice and concern. }\end{array}$ \\
\hline 2007 & Karakose & $\begin{array}{l}\text { - conducted a quantitative study of teachers 'perceptions of } \\
\text { principals' ethical leadership in Turkey. } \\
\text { - using the Ethical Leadership Scale questionnaire developed by } \\
\text { Yilmaz (2006) and contains four dimensions: ethical } \\
\text { communication, ethical climate, ethical decision making and } \\
\text { ethical behaviour. }\end{array}$ \\
\hline 2008 & $\begin{array}{l}\text { De Hoogh } \\
\text { and } \\
\text { Hartog }\end{array}$ & $\begin{array}{l}\text { - developing three specific dimensions of justice, power sharing } \\
\text { and role clarification through literature studies. }\end{array}$ \\
\hline 2009 & Bowers & $\begin{array}{l}\text { - a study of } 209 \text { Ohio school teachers found that teachers' } \\
\text { perceptions of ethical leadership had a strong impact on teacher } \\
\text { commitment in schools. }\end{array}$ \\
\hline
\end{tabular}


INTERNATIONAL JOURNAL OF ACADEMIC RESEARCH IN BUSINESS AND SOCIAL SCIENCES Vol. 10, No. 9, 2020, E-ISSN: 2222-6990 @ 2020 HRMARS

\begin{tabular}{|c|c|c|}
\hline & & $\begin{array}{l}\text { - using the Ethical Leadership Scale (ELS) developed by Brown et al. } \\
\text { (2005). }\end{array}$ \\
\hline 2011 & Chambers & $\begin{array}{l}\text { - a study of } 650 \text { high school teachers in the United States of } \\
\text { Tennessee found that teachers' perceptions of school principals } \\
\text { were related to school excellence. } \\
\text { - using the Perceived Leadership Integrity Scale (PLIS) developed } \\
\text { by Craig and Gustafson (1998). }\end{array}$ \\
\hline 2011 & $\begin{array}{l}\text { Kalshoven, } \\
\text { De Hoogh } \\
\text { and Den } \\
\text { Hartog }\end{array}$ & $\begin{array}{l}\text { - encompassing seven dimensions of ethical leadership, namely } \\
\text { human-oriented, justice, power-sharing, concern for sustainability, } \\
\text { ethical guidance, role clarification and integrity. } \\
\text { - Develop a multidimensional ethical leadership measurement } \\
\text { called Ethical Leadership at Work (ELW). }\end{array}$ \\
\hline 2013 & $\begin{array}{l}\text { Patterson, } \\
\text { Campbell, } \\
\text { Johnson, } \\
\text { Marx and } \\
\text { Whitener }\end{array}$ & $\begin{array}{l}\text { - concludes that management plays a key role in implementing } \\
\text { educational reforms, while striving to maintain its own priorities } \\
\text { and values. }\end{array}$ \\
\hline 2014 & $\begin{array}{l}\text { Langlois, } \\
\text { Lapointe, } \\
\text { Valois and } \\
\text { Leeuw }\end{array}$ & $\begin{array}{l}\text { - conducting quantitative research and developing the Ethical } \\
\text { Leadership Questionnaire (ELQ) }\end{array}$ \\
\hline 2015 & Viet & $\begin{array}{l}\text { - states that organizational ethical leadership is focused on } \\
\text { structure and efficiency and comes with decision-making power. } \\
\text { - Ethical leadership of the organization demonstrates compliance } \\
\text { with internal and external regulations through remuneration }\end{array}$ \\
\hline 2016 & $\begin{array}{l}\text { Shapiro and } \\
\text { Stefkovich }\end{array}$ & $\begin{array}{l}\text { - study ethical leadership from the perspective of complex } \\
\text { dilemma theory. }\end{array}$ \\
\hline 2016 & $\begin{array}{l}\text { Lapointe, } \\
\text { Langlois, } \\
\text { Valois, Aksu, } \\
\text { Arar, } \\
\text { Bezzina, } \\
\text { Johansson, } \\
\text { Norberg and } \\
\text { Oplatka }\end{array}$ & $\begin{array}{l}\text { - conducted research in } 5 \text { countries (Canada, Sweden, Israel, Malta, } \\
\text { Turkey) to validate the Ethical Leadership Questionnaire (ELQ). }\end{array}$ \\
\hline 2017 & $\begin{array}{l}\text { Schechter } \\
\text { and Shaked }\end{array}$ & $\begin{array}{l}\text { - conducting studies that consider the characteristics and } \\
\text { circumstances of the school. }\end{array}$ \\
\hline 2018 & Dinc & $\begin{array}{l}\text { - has examined the direct and indirect effects of the relationship } \\
\text { between ethical leadership, types of ethical climate, aspects of job } \\
\text { satisfaction, organizational commitment components and } \\
\text { organizational citizenship behaviors of } 515 \text { employees working in } \\
\text { public and private universities in Bosnia and Herzegovina. }\end{array}$ \\
\hline
\end{tabular}


INTERNATIONAL JOURNAL OF ACADEMIC RESEARCH IN BUSINESS AND SOCIAL SCIENCES Vol. 10, No. 9, 2020, E-ISSN: 2222-6990 @ 2020 HRMARS

\begin{tabular}{|l|l|l|}
\hline 2019 & Lowery & $\begin{array}{l}\text { - conducted a study on principals' perceptions of southeastern } \\
\text { Ohio on decision-making ethics. }\end{array}$ \\
\hline 2019 & $\begin{array}{l}\text { Oduol and } \\
\text { Cornforth }\end{array}$ & $\begin{array}{l}\text { - studied the ethical behavior of school leaders in non-Euro-West } \\
\text { countries by examining the dilemmas faced by Kenyan educational } \\
\text { leaders. }\end{array}$ \\
\hline
\end{tabular}

\section{Conclusion}

The literature review that has been described shows several gaps related to the impact of ethical leadership in the context of educational management. To fill this gap is a lot of research that can be conducted in the future using theories and other sources of support.

\section{References}

Arar, K., Haj, I., Abramovitz, R., Oplatka, I. (2016) Ethical leadership in education and its relation to ethical decision-making: The case of Arab school leaders in Israel, Journal of Educational Administration, Vol. 54 Issue: 6, pp.647-660.

Benoliel, P., Shaked, H., Nadav, N., and Schechter, C. (2019), "School principals' systems thinking: antecedents and consequences", Journal of Educational Administration, Vol. 57 No. 2, pp. 167184. https://doi.org/10.1108/JEA-08-2018-0144.

Brownell, J. (2006). Meeting the Competency Needs of Global Leaders: A Partnership Approach. Human Resource Management 45(3): 309-336.

Brown, M. E., \& Mitchell, M. S. (2010). Exploring new avenues for future research. Business Ethics Quarterly, 4(October), 583-616.

Brown, M. E., \& Trevino, L. K. (2006). Ethical leadership: A review and future directions. The Leadership Quarterly, 17(6), 595-616.

Brown, M. E., Treviño, L. K., \& Harrison, D. A. (2005). Ethical leadership: A social learning perspective for construct development and testing. Organizational Behavior and Human Decision Processes, 97(2), 117-134.

Cherkowski, S., Walker, K.D. and Kutsyuruba, B. (2015), Principals' moral agency and ethical decisionmaking: towards a transformational ethics, International Journal of Educational Policy and Leadership, Vol. 10 No. 5, pp. 1-17.

Chambers, J. H. (2011). The relationship between secondary school teachers' perceptions of principal ethical leadership and organizational health. Tesis PhD yang tidak diterbitkan. University of Tennessee.

Ciulla, J. B. (1995). Leadership ethics: Mapping the territory. Business Ethics Quarterly, 5(1), 5-28.

Ciulla, J. B. (1998). Ethics, the heart of leadership. Westport, CT: Quorum Books.

Ciulla, J. B. (2005). The state of leadership ethics and the work that lies before us. Business Ethics: $A$ European Review, 14(4), 323-335.

Dempster, N., Freakley, M., \& Parry, L. (1998). A paper presented at the Annual conference of the Australian Association for Educational Research, Adelaide, November, 1998. In A study of the ethical decision making of school principals.

Dempster, N., Freakley, M., \& Parry, L. (2000). The ethical decision making of school principals: Survey results. 
INTERNATIONAL JOURNAL OF ACADEMIC RESEARCH IN BUSINESS AND SOCIAL SCIENCES

Vol. 10, No. 9, 2020, E-ISSN: 2222-6990 @ 2020 HRMARS

Den Hartog, D. N., \& Belschak, F. D. (2012). When does transformational leadership enhance employee proactive behavior? The role of autonomy and role breadth self-efficacy. Journal of Applied Psychology, 97(1), 194-202.

Den Hartog, D. N., \& De Hoogh, A. H. B. (2009). Empowering behaviour and leader fairness and integrity: Studying perceptions of ethical leader behaviour from a levels-of-analysis perspective. European Journal of Work an Organizational Psychology, 18(2), 199-230.

Dinc, M. S. (2018) 'Direct and indirect effect of ethical leadership on employee behaviours in higher education', Int. J. Management in Education, Vol. 12, No. 3, pp.201-222.

Hodgkinson, C. (1978), Towards a Philosophy of Administration, Oxford: Basil Blackwell.

Hodgkinson, C. (1991). Educational leadership: The moral art. Albany, NY: State University of New York Press.

Holte, K. (2014), The prevalence of silence, in Branson, C.M. and Gross, S.J. (Eds). The Handbook of Ethical Educational Leadership, Routledge, New York, NY, pp. 139-150.

Hu, Z. F., Li, Q. M., \& Zou, S. X. (2015). Research on the Structure of Principal's Moral Leadership in Middle Schools in Mainland China. Creative Education, 6, 798-804.

Jokinen, T. (2005). Global Leadership Competencies: A Review and Discussion. Journal of European Industrial Training 29 (3): 199-216.

Kalshoven, K., \& Boon, C. T. (2012). Ethical leadership, employee well-being, and helping: The moderating role of human resource management. Journal of Personnel Psychology, 11(1), 6068.

Kalshoven, K., Den Hartog, D. N., \& De Hoogh, A. H. (2011a). Ethical leader behavior and big five factors of personality. Journal of Business Ethics, 100(2), 349-366.

Kalshoven, K., Den Hartog, D. N., \& De Hoogh, A. H. (2011b). Ethical leadership at work questionnaire (ELW): Development and validation of a multidimensional measure. The Leadership Quarterly, 22(1), 51-69.

Kalshoven, K., Den Hartog, D. N., \& De Hoogh, A. H. (2013). Ethical leadership and follower helping and courtesy: Moral awareness and empathic concern as moderators. Applied Psychology: An International Review, 62(2), 211-235.

Kantor, J., \& Weisberg, J. (2012). Ethical attitudes and ethical behaviour: are managers role models? International Journal of Manpower, 23(8), 687-703.

Kanungo, R. N. (2001). Ethical values of transactional and transformational leaders. Canadian Journal of Administrative Sciences, 18, 257-265.

Kanungo, R. N., \& Conger, J. A. (1993). Promoting altruism as a corporate goal. The Academy of Management of Executive, 7, 37-48.

Kanungo, R. N., \& Mendonca, M. (1996). Ethical dimensions of leadership. Thousand Oaks, CA: Sage Publications.

Langlois, L., \& Lapointe, C. (2007). Ethical leadership in Canadian school organizations: Tensions and possibilities. Educational Management, Administration, and Leadership, 35(2), 247-60.

Langlois, L., Lapointe, C., Valois, P., \& de Leeuw, A. (2014). Development and validity of the Ethical Leadership Questionnaire, Journal of Educational Administration, 52(3), 310-331.

Lapointe, C., Langlois, L., Valois, P., Aksu, M., Arar, K., Bezzina, C., Johansson, O., Norberg, K., and Oplatka, I. (2016). An International Cross-Cultural Validation of the Ethical Leadership Questionnaire (ELQ). International Studies in Educational Administration, 44(2), 55-76. 
INTERNATIONAL JOURNAL OF ACADEMIC RESEARCH IN BUSINESS AND SOCIAL SCIENCES

Vol. 10, No. 9, 2020, E-ISSN: 2222-6990 @ 2020 HRMARS

Lowery, C. (2019), "Moral literacy and school leadership: Perceptions of principals in southeast Ohio on the ethics of decision-making", Journal of Educational Administration, Vol. 58 No. 1, pp. 112127. https://doi.org/10.1108/JEA-06-2018-0120

Mann, L., Burnett, P., Radford, M., \& Ford, S. (1997). The Melbourne Decision Making Questionnaire: An instrument for measuring patterns for coping with decisional conflict. Journal of Behavioral Decision Making, 10(1), 1-19.

Mayer, D. M., Kuenzi, M., \& Greenbaum, R. L. (2010). Examining the link between ethical leadership and employee misconduct: The mediating role of ethical climate. Journal of Business Ethics, 95, 7-16. doi:10.1007/s10551-011-0794-0.

McMillan, J. H. (2008). Educational Research: Fundamentals for the Consumer. (5 $5^{\text {th }}$ Ed.) Pearson.

Mendonca, M. (2001). Prepairing for ethical leadership in organizations. Canadian Journal of Administrative Sciences, 18(4), 266-276.

Merriam, S. B. (1988). Case Study Research in Education: A Qualitative Approach. San Francisco, California: Jossey Bass Publishers.

Meyer, J. P., Stanley, D. J., Herscovitch, L., \& Topolnytsky, L. (2002). Affective, continuance, and normative commitment to the organization: A meta-analysis of antecedents, correlates, and consequences. Journal of Vocational Behavior, 61(1), 20-52.

Miller, S. J., Hickson, D. J., \& Wilson, D. C. (1996). Decision making in organizations. In S.R. Clegg, C. Hardy, \& W.R. Nord (Eds.), Managing Organizations: Current Issues (pp.43-62). London: Sage Publications.

Mintzberg, H., Raisinghani, D., \& Theoret, A. (1976). The structure of "unstructured" decision processes. Administrative Science Quarterly, 21, 246-275.

Mitchelmore, S., and Rowley, J. (2009), "Entrepreneurial competencies: literature review and development agency", International Journal of Entrepreneurial Behavior and Research, Vol. 16 No. 2, pp. 92-111.

Norberg, K. (2009). School leadership for diversity and inclusion: Meeting the multicultural challenge in Sweden. Values and Ethics in Educational Administration, 8(1), 1-8.

Norberg, K., \& Johansson, O. (2014). The ethical demands of multiculturalism. In C. M. Branson \& S. J. Gross (Eds.), Handbook of ethical educational leadership (pp. 426-438). New York: Routledge.

Noddings, N. (1984). Caring: A feminine approach to ethics and moral education. Berkeley, CA: University of California Press.

Azmi, N. (2006). Hubungan antara komitmen ahli pasukan dengan keberkesanan pasukan kerja dalam jabatan sains dan matematik di daerah Tumpat. Tesis Sarjana Muda Yang Tidak Diterbitkan. Skudai: Universiti Teknologi Malaysia.

Nucci, L. P. (2015). Education in the moral domain. New York, NY: Cambridge University Press.

Oduol, T., and Cornforth, S. (2019), "Ethical dilemmas in education: a case study of challenges faced by secondary school leaders in Kenya", Journal of Educational Administration, Vol. 57 No. 6, pp. 601-614. https://doi.org/10.1108/JEA-05-2017-0060

Patterson, J. A., Campbell, J. K., Johnson, D. M., Marx, G., \& Whitener, M. (2013). Using policy attributes theory to examine comprehensive school reform implementation in two Title I middle schools. Planning \& Changing, 44(1/2), 36-55.

Payne, J. W., Bettman, J. R., \& Luce, M. E (1996). When time is money: An investigation of decision behavior under opportunitycost time pressure. Organizational Behavior and Human Decision Processes, 66, 131-152. 
INTERNATIONAL JOURNAL OF ACADEMIC RESEARCH IN BUSINESS AND SOCIAL SCIENCES

Vol. 10, No. 9, 2020, E-ISSN: 2222-6990 @ 2020 HRMARS

Peterson, D. K. (2002). The relationship between unethical behaviour and the dimensions of the ethical climate questionnaire. Journal of Business Ethics, 41(4), 313-326. doi:10.1023/A:1021243117958.

Piccolo, R. F., \& Colquitt, J. A. (2006). Transformational leadership and job behaviors: The mediating role of core job characteristics. Academy of Management Journal, 49(2), 327-340.

Piccolo, R. F., Greenbaum, R., Den Hartog, D. N., \& Folger, R. (2010). The relationship between ethical leadership and core job characteristics, 278(April 2009), 259-278. doi:10.1002/job

Pierce, M. A., \& Henry, J. W. (2000). Judgements about computer ethics: Do individual, co-worker, and company judgements differ? Do company codes make a difference? Journal of Business Ethics, 28(4), 307-322.

Pijanowski, J. (2007). Defining moral leadership in graduate schools of education. Journal of Leadership Education, 6(1), 1-13.

Podsakoff, M., Mackenzie, S. B., Moorman, R. H., \& Fetter, R. (1990). Transformational leader behaviors and their effects on followers' trust in leader, satisfaction, and organizational citizenship behaviors. Leadership Quarterly, 1(2), 107-142.

Reason, J. (1997). Managing the Risks of Organizational Accidents. Aldershot, UK: Ashgate.

Resick, C. J., Hanges, P. J., Dickson, M. W., \& Mitchelson, J. K. (2006). A cross-cultural examination of the endorsement of ethical leadership. Journal of Business Ethics, 63, 345-359.

Roepke, W. J. (2011). Morality as a yardstick of educational leadership. Journalism and Mass Communication Educator, 50(2), 71-76.

Marican, S. (2006). Membentuk suasana kerja positif: Kuala Lumpur: Utusan Publication \& Distributors Sdn Bhd.

Said, J., Alam, M. M., Khalid, M. (2016). Relationship between Good Governance and Integrity System: Empirical Study on the Public Sector of Malaysia. Humanomics. Vol. 32(2), pp. 151-171.

Schechter, C., and Shaked, H. (2017), "Leaving fingerprints: principals' considerations while implementing education reforms", Journal of Educational Administration, Vol. 55 No. 3, pp. 242-260. https://doi.org/10.1108/JEA-01-2016-0014

Schneider, B. (1990). Organizational climate and culture. San Francisco, CA: Jossey-Bass.

Sergiovanni, T. J. (2001). Leadership: What's in it for schools? London: Routledge.

Sethi-lyengar, S., Huberman, G., and Jiang, W. (2004) "How Much Choice Is Too Much? Contributions to 401(k) Retirement Plans, "New Lessons from Behavioral Finance New York (83-95). Oxford University Press.

Shapira-Lishchinsky, O., \& Rosenblatt, Z. (2009). Organizational Ethics and Teachers' Intent to Leave: An Integrative Approach. Educational Administration Quarterly, 45(5), 725-758.

Shapiro, J. P., \& Stefkovich, J. A. (2016) Ethical Leadership and Decision Making in Education: Applying Theoretical Perspectives to Complex Dilemmas, 4th ed. New York, N.Y.: Routledge.

Silins, H. C., \& Harvey, K. (2000). Perseption of effectiveness: A study of schools in Victoria. Journal of American Academy of Business, Cambridge, 392-412.

Johar, S. S. B. (2006). Gaya Kepimpinan Pengetua dan Hubunganya Dengan Tahap Motivasi Guru Di Sekolah Menengah Daerah Kota Tinggi. Tesis Sarjana, UTM.

Smylie, M. A., Conley, S., \& Marks, H. (2002). Exploring new approaches to teacher leadership for school improvement. In J. Murphy (Ed.) The educational leadership challenge: Redefining leadership for the 21st century (162-188). University of Chicago Press. 
INTERNATIONAL JOURNAL OF ACADEMIC RESEARCH IN BUSINESS AND SOCIAL SCIENCES Vol. 10, No. 9, 2020, E-ISSN: 2222-6990 @ 2020 HRMARS

Somech, A. (2005). Directive Versus Participative Leadership: Two Complementary Approaches to Managing School Effectiveness. Education Administration Quarterly, 41(5), 777-800.

Somech, A., \& Bogler, R. (2002). Antecedents and consequences of teacher organizational and professional commitment. Educational Administration Quarterly, 38 (4), 555-577.

Somers, J. M. (2001). Ethical codes of conduct and organizational context: A study of the relationship between codes of conduct, employee behavior and organizational values. Journal of Business Ethics, 30(2), 185-195.

Sowell, E. J. (2001). Educational Research: An Integrative Introduction. New York: McGraw-Hill, Inc.

Starratt, R. J. (1991). Building an Ethical School: A Theory for Practice in Educational Leadership. Educational Administration Quarterly, 27(2), 185- 202.

Starratt, R. J. (2003). Opportunity to learn and the accountability agenda. Phi Delta Kappan 85(4): 298-303.

Starratt, R. J. (2004). Ethical leadership. San Francisco: Jossey-Bass.

Strike, K. (2007). Ethical leadership in schools: Creating community in an environment of accountability. London: Corwin Press.

Tamir, E., and Arar, K. (2019), "High school managements resources allocation in an era of reforms", International Journal of Educational Management, Vol. 33 No. 5, pp. 828847. https://doi.org/10.1108/IJEM-08-2017-0204.

Tenbrunsel, A. E., \& Messick, D. M. (1999). Sanctioning systems, decision frames, and cooperation. Administrative Science Quarterly, 44(4), 684-707. doi:10.2307/2667052.

Trevino, L. K. (1986). Ethical decision-making in organizations: A person-situation interactionist model. Academy of Management Review, 11(3), 601-617.

Trevino, L. K., Brown, M., \& Hartman, L. P. (2003). A qualitative investigation of perceived executive ethical leadership: Perceptions from inside and outside the executive suite. Human Relations, 56, 5-37.

Ubben, G. C., Hughes, L. W., \& Norris, C. J. (2007). The principal: Creative leadership for excellence in schools (6th ed.). Boston: Allyn and Bacon.

Verstegen, D. A. (2012). Financing the new adequacy: towards new models of state education finance systems that support standards-based reform. Journal of Educational Finance, 27, 3, 749-81.

Victor, B., \& Cullen, J. B. (1988). The organizational bases of ethical work climates. Administrative Science Quarterly, 33(1), 101-125.

Walumbwa, F. O., Avolio, B. J., Gardner, W. L., Wernsing, T. S., \& Peterson, S. J. (2008). Authentic Leadership: Development and Validation of a Theory-Based Measure. Journal of Management, 34(1), 89-126.

Walumbwa, F. O., Mayer, D. M., Wang, P., Wang, H., Workman, K., \& Christensen, A. L. (2011). Linking ethical leadership to employee performance: The roles of leader-member exchange, selfefficacy, and organizational identification. Organizational Behaviour and Human Decision Processes, 115(2), 204-213.

Washington, R. R., Sutton, C. D., \& Field, H. S. (2006). Individual differences in servant leadership: The role of values and personality. Leadership \& Organization Development Journal, 27(8), 700716.

Watts, D. S., and Richardson, J. W. (2020), "Leveraging professional development to build professional capital in international schools in Asia", Journal of Professional Capital and 
INTERNATIONAL JOURNAL OF ACADEMIC RESEARCH IN BUSINESS AND SOCIAL SCIENCES

Vol. 10, No. 9, 2020, E-ISSN: 2222-6990 @ 2020 HRMARS

Community, Vol. ahead-of-print No. ahead-of-print. https://doi.org/10.1108/JPCC-09-20190025.

Wimbush, J. C., Shepard, J. M., \& Markham, S. E. (1997). An empirical examination of the relationship between ethical climate and ethical behavior from multiple levels of analysis. Journal of Business Ethics, 16(16), 1705-1716.

Yukl, G., Mahsud, R., Hassan, S., \& Prussia, G. E. (2013). An improved measure of ethical leadership. Journal of Leadership \& Organizational Studies.

Yukl, G. A. (1981). Leadership in organizations. Englewood Cliffs, NJ: Prentice-Hall.

Zhu, W. (2008). The effect of ethical leadership on follower moral identity: The mediating role of psychological empowerment. Leadership Review, 8, 62-73.

Zikmund, W. G., Babin, B. J., Carr, J. C., \& Griffin, M. (2010). Business research methods (8th ed.). Mason, HO: Cengage Learning.

Zimmerman, M. A., \& Rappaport, J. (1988). A citizenship participation, perceived control, and psychological empowerment. American Journal of Community Psychology, 16(5), 725-750. 